University of Louisville

ThinkIR: The University of Louisville's Institutional Repository

\title{
Reflective tales : tracing fairy tales in popular culture through the depiction of maternity in three "Snow White" variants.
}

\author{
Alexandra O'Keefe \\ University of Louisville
}

Follow this and additional works at: https://ir.library.louisville.edu/honors

Part of the Children's and Young Adult Literature Commons, and the Comparative Literature Commons

\section{Recommended Citation}

O'Keefe, Alexandra, "Reflective tales : tracing fairy tales in popular culture through the depiction of maternity in three "Snow White" variants." (2014). College of Arts \& Sciences Senior Honors Theses. Paper 62.

http://doi.org/10.18297/honors/62

This Senior Honors Thesis is brought to you for free and open access by the College of Arts \& Sciences at ThinkIR: The University of Louisville's Institutional Repository. It has been accepted for inclusion in College of Arts \& Sciences Senior Honors Theses by an authorized administrator of ThinkIR: The University of Louisville's Institutional Repository. This title appears here courtesy of the author, who has retained all other copyrights. For more information, please contact thinkir@louisville.edu. 
Reflective Tales:

Tracing Fairy Tales in Popular Culture through the Depiction of Maternity in Three "Snow White" Variants

By

Alexandra O’Keefe

Submitted in partial fulfillment of the requirements for Graduation summa cum laude

University of Louisville

March, 2014 
The ability to adapt to the culture they occupy as well as the two-dimensionality of literary fairy tales allows them to relate to readers on a more meaningful level. In most of these tales characters are cast as good or evil, clever or dull, beautiful or ugly, with good reigning triumphant. Leaving little room for moral ambiguity, the fairy tale often ensures that the end of the tale, through the punishment or death of evil characters, maintains order. In this way they become mirrors for the ideals, values, practices, and perceptions of the societies from which they originate. This remains the case with modern day variants of 'classic' literary tales. From film to television, these tales have continually been a staple of American popular culture, with a boom in fairy tale production in recent years. Shows like Grimm (2011) and Once Upon a Time (2011) bring modern spins on fairy tales into people's living rooms, while live action movies like Hansel and Gretel: Witch Hunters (2013), Jack the Giant Slayer (2013), Snow White and the Huntsman (2012), and Red Riding Hood (2011) bring audiences to theatres in droves. There is no denying the push for fairy tales in current American media: a new film comes out almost yearly while the TV shows are surviving increasing network cancellations to tell more stories, with some series now continuing into their second and third seasons.

When questioning why they have returned with such fervor the answer is never simple. Fairy tales have found popularity in a number of social and historical contexts before now - some stable, such as the French courts of Perrault's time, others tumultuous, like Germany during the Grimm Brothers' lifetimes. The Grimms began their collection of tales during the Napoleonic Wars, when the French created a politically unstable environment in Germany, a situation “... most disquieting for both Jacob and Wilhelm, who were dedicated to the notion of a German unification. Neither wanted to see the restoration of oppressive German princes, but they did feel a deep longing to have the German people united in one nation through customs and laws of their 
own making” (Zipes, The Brothers Grimm 6). This hope for unification was primarily what drove projects like Kinder und Hausmärchen (Children's and Household Tales) for the Grimms. Their final collection of 211 stories in the seventh edition of Kinder und Hausmärchen often reflects their desire to capture tales that would bring people together while maintaining values that they felt should be emulated. Like the Grimms, the iconic figurehead of fairy tales in American, Walt Disney, found his early success during a restless period of history. His first feature length film, Snow White and the Seven Dwarfs (1937), packed theatres despite the Great Depression $^{1}$. Moreover, the film “... became a huge critical, popular and financial success for the Disney studio, and would earn $\$ 8$ million by the end of its first run” (Davis 90). This is impressive enough, but even more so when taking into account that early in the Depression, theatre admission dropped from "80 million in 1930 to 55 million in 1932," yet Disney filled enough seats to gross millions (Ashby 222). Arguably American fairy tale media is prospering under similar conditions today. Part of their appeal is the perennial hope that good will triumph in the end, and most current fairy tale films continue to have happy endings. While the television shows cannot afford for good to always win if they are going to keep audiences interested, they do present the protagonists as more successful more often than the forces they fight. Ultimately this simplistic view of the world can be comforting to a society surrounded by daily anxieties (ranging from the falling economy to terrorism in post 9/11 America.)

In considering the vast number of fairy tales and their variants, it is impossible to declare that any one would create a holistic reflection of the society for which it was produced. The Grimms' tales collectively may represent their German readership, but that does not mean certain

\footnotetext{
${ }^{1}$ For the purpose of this discussion "Disney" is in reference to the company and the brand while "Walt Disney is in reference to the man. Unless otherwise noted, "Disney" and "Disney films" is in reference to those during Walt Disney's influence: ranging from Snow White and the Seven Dwarfs in 1937 through The Jungle Book in 1967. After those dates different approaches to the tales occur due to different leaders of the corporation and changes in the desires of the American consumer.
} 
stories those readers more than others. The fact that tales like "Die drei Federn" ("The Three Feathers") and "Die Hochzeit der Frau Füchsin” (“The Wedding of Mrs. Fox") are not commonly known, but "Hänsel und Gretel” ("Hansel and Gretel”) and "Dornröschen” ("Briar Rose") are remembered, is a testament to this impact. When considering tales that have greatly influenced popular culture a select group comes to mind, but few can compare to the popularity of (ATU 709), "Sneewittchen" (or "Schneewittchen" or "Schneewießchen" depending on the version), known in English as "Snow White." ${ }^{2}$ Being the first tale Disney animated in a feature length film, "Snow White" bridges a gap between the Grimms and Disney, and plays a prominent role in the well-received American Broadcasting Corporation (ABC) produced television series Once Upon a Time (created by Adam Horowitz and Edward Kitsis.) ${ }^{3}$ Few tales have shifted so much over time as "Snow White," creating new societal reflections with each new variant.

While all versions vary from their predecessors, the elements that remain act as a starting point to consider how they have truly changed from version to version. In the case of "Snow White" the central female characters, the child and her stepmother, are never removed, creating a stage for perpetual female discord. The unnatural mother, the source of discord, appears in all three variants used for this discussion, but her alterations over time from the Grimms to Once Upon a Time create a more complicated view of this mother as an adversary. Meanwhile, the character of Snow White moves further into a maternal role across these "Snow White" tales, creating differing stuggles between the female characters, that moves into a "good mother" against "bad mother" arena (to borrow the Freudian terminology) instead of a power struggle

\footnotetext{
2 The title "Snow White" will be used in reference to this tale from this point on for both continuity and ease for the reader.

${ }^{3}$ When Once Upon a Time premiered on October 23, 2011 it “...enchanted 12.8 million viewers, making it [that] fall's highest-rated drama debut" according to one report (Hibberd).
} 
between parent and child. A close examination of these three texts (Grimm's variant, Disney's 1937 film, and ABC's Once Upon a Time) reveal striking changes in the treatment of maternity from the Disney film's recasting of Freudian "good and bad mothers" to Once Upon a Time's new look at the warrior mother - reflecting a broader transformation in their respective societal attitudes, both through their connection to and their departures from the tales that precede them.

\section{The Brothers Grimm: Before Popular Culture}

The Grimms were not the first to begin collecting and publishing folklore in Germany; they are, however, one of the more successful cases. This success comes from a number of factors, such as their ability to construct and present relatable stories. Reflecting the ideals and desires of such a large group is synonymous with the function of modern popular culture. It departs from the 'high' or literary culture, moving instead into a middle position that works to represent both the 'folk' and the upper-middle class and seeking to reach a wide audience by reflecting readers' understandings of themselves as a culture.

It comes as no surprise that "Snow White" has literary ancestors, given the rich array of variants in ATU709. Johann Karl August Musäus' story, "Richilde," published in 1782 in his collection Volksmärchen der Deutschen (Tales of the Germans) predates the first publication of "Snow White" by thirty years. This tale about a princess, Blanca, and her stepmother, Richilde, shares some elements with the Grimm variant, such as the fruit turned weapon and the red-hot shoes. Yet some scholars do not wholly accept that it shouldn't be categorized as a fairy tale like the Grimms' tale despite the similarities. Christine Shojaei Kawan argues that the Musäus' tale "is not a märchen but a parodic tale which vacillates between the novelistic, the legendary and the moralistic modes..." (Kawan 337). Not regarding it as a fairy tale, as Kawan suggests, alters 
its relationship to the Grimms' tale, placing different standards based on genre onto the Grimms' story. Lines between fairy tales, legends, and folk tales have remained blurry over time, however, often making their distinctions difficult to declare. Kawan does point out a large difference beyond the structure, though, that alters their interpretations of "Snow White" and "Richilde." Kawan notes that the Musäus tale focuses more on Richilde than Blanca, marking a drastic difference from the Grimms' version's Snow White who is central despite her powerful stepmother (Kawan 331). The Grimms highlight Snow White's good deeds, while the stepmother appears only in relation to the protagonist, creating a two-dimensional character when compared to Richilde (whose motivating, crippling vanity is explained through her extensive back story.) In comparison to Richilde, the Grimms' stepmother is not even named, but referred to as "die Königin" (the queen) and "die Stiefmuter" (the stepmother).

"Richilde" may predate "Snow White," but that does not make it the more useful of the two texts. The Grimms' version carries more weight, as it is the better known and arguably (based on Kawan's opinion) the only one of the two that can be classified as a true fairy tale. However, ruling out Musäus' story would rule out any variant that doesn't fit neatly within the fairy tale genre, making modern examples like Disney's films not considerable as fairy tale variants. This murky division of what is a 'true' fairy tale and what isn't in current scholarship contributes to this conundrum, but in the case of the "Snow White" tale Musäus' text should be placed in the same category. While it may be long and complex, it shares the themes of vanity, malice, and innocence that are at the core of the tale as it is defined as a type. Therefore it should be considered in the same league as the Grimms' as well as Disney's "Snow White" versions. Interestingly these themes place an emphasis on women's conflict, which remains present in the much later Once Upon a Time. 
For the Grimms, Musäus and Disney, however, the stepmother's envy is the source of conflict despite their many differences. In the Grimm variant, after the queen is told she is no longer the fairest, the story states: ${ }^{4}$

"Von Stund an, wenn sie Schneewittchen erblickte, kehrte sich ihr das Herz im Leibe herum, so hasste sie das Mädchen. Und der Neid und Hochmut wuschen wie ein Unkraut in ihrem Herzen immer höher, dass sie Tag und Nacht keine Ruhe mehr hatte" (Grimm, Schneewittchen 13).

"From that moment on she hated Snow White, and whenever she set eyes on her, her heart turned cold like a stone. Envy and Pride grew as fast as weeds in her heart. By day or night she never had a moment's peace" (Grimm, "Snow White" 251).

This envy is argued to exist for a number of reasons. However, no matter what analytical perspective is taken, the emphasis on the importance of motherhood is retained. Freudian and feminist approaches both work to expand upon our understanding of the roles of mother and child, but in different ways.

In his influential book on the Freudian interpretation of fairy tales, The Uses of Enchantment, Bruno Bettelheim focuses largely on the Oedipal conflicts between parents and children when interpreting many Grimm tales. In the case of "Snow White," he believes "the story deals essentially with the Oedipal conflicts between mother and daughter..." (Bettelheim 202). He gives both Snow White and her stepmother equal attention by placing their Oedipal struggles into two different chapters, titled: “The Jealous Queen in 'Snow White' and the Myth of Oedipus," and simply "Snow White." Bettelheim uses "Snow White” as a vehicle by which to

\footnotetext{
${ }^{4}$ Due to mistranslations that can often occur when omitting the original language completely, German will be used for long quotes. However, Maria Tartar's translation does an excellent job remaining "faithful to the cadences of the Grimms'...text," and will thus be used for alternate English quotations for non-German readers (Smith 108).
} 
discuss the Oedipus Complex from both angles: the mother's unresolved complex, and the child's emerging one. Normally attention is wholly paid to the child as he or she struggles through the Oedipal stages, but Bettelheim argues that the stepmother in "Snow White" is relatable to Laius, the murdered father in the Oedipus myth. Like Laius, the stepmother's inability to overcome the Oedipal stage causes her to be destroyed by her fear of being replaced by her child (Bettelheim 195). At the same time, Snow White works through her own psychological struggles by rejecting the mother who is threatening a development of her new identity garnered through puberty. Under this interpretation it makes perfect sense that the stepmother is supernaturally strong, because a parent seems invincible from a child's perspective.

While Bettelheim's specific analysis of "Snow White" reveals these oedipal conflicts, a general chapter on stepmothers sheds light on the relationship between Snow White and her stepmother. To Bettelheim stepmothers represent the "bad mother" when children can't reconcile the "good" and "bad." He states that this split "is not only a means of preserving an internal allgood mother..., but it also permits anger at this bad 'stepmother' without endangering the goodwill of the true mother, who is viewed as a different person" (Bettelheim 69). In this way the mother and stepmother are one and the same, making the presence of Snow White's natural mother in the Grimms' text very important to understanding the motives behind the struggle later in the story. The death of the natural mother is the sign that the child no longer views her mother as good, ushering the introduction of the stepmother.

In considering another perspective, one of the most referenced feminist analyses of "Snow White" comes from Sandra M Gilbert and Susan Gubar, who believe "the real story begins when the Queen, having become a mother, metamorphoses also into a witch ..." (Gilbert 
and Gubar 37). The first chapter of their book, The Madwoman in the Attic, closely analyzes the women in the Grimms' tale, focusing on the concept of "the angel-woman and the monsterwoman" (Gilbert 36). Their theory is that the window and the mirror act as frames for the natural mother and stepmother respectively, inviting the comparison between the natural mother's physical interiority and the stepmother's emotional interior. At the start of the Grimms' tale, Snow White's future mother sews at an ebony window while looking out at the snow. She pricks her finger and after three drops fall she thinks:

“Hätt' ich ein Kind, so weiß wie Schnee so schön wie Blut und so Schwarz wie das Holz an dem Rahmen!” (Grimm, Schneewittchen 6).

"If only I had a child as white as snow, as red as blood, and as black as the wood of the window frame" (Grimm, "Snow White" 249).

She dies soon after giving birth to Snow White, only playing a small part in the overall plot. However, her presence is loaded with symbolism. According to Gilbert and Gubar she represents the good wife who wishes to be a mother, quietly performs her duties, and remains inside her home. She is the definition of the patriarchy's "angel woman," unlike her monstrous counterpart. Instead of a shift in the child's perception changing the good mother into the bad, as Bettelheim suggests, Gilbert and Gubar argue that her transformation comes from the realization that she "is doomed to the inward search that...is necessitated by a state from which all outward prospects have been removed" (Gilbert and Gubar 37). Gilbert and Gubar's theory makes the adult character the interpreter of events, and in this way Snow White is a representation of the reincarnation of the natural mother prior to her replacement by the stepmother. To the stepmother Snow White is a reminder of the "angel woman" she once was and can never be 
again, and so she is driven to rid herself of the child. The introduction to the stepmother states that she was:

“...eine schöne Frau, aber sie war stolz und übermütig und konnte nicht leiden, dass sie an Schönheit von jemand sollte übertroffen werden" (Grimm, Schneewittchen 9).

"... a beautiful lady, but proud and domineering, and she could not bear the thought that anyone might be more beautiful than she was..." (Grimm, "Snow White" 250).

This passage is not directly quoted in Gilbert and Gubar's sudy, however it sets up the relationship between Snow White and the stepmother in the same terms. Inevitably Snow White will become more beautiful than the queen, and therefore Snow White represents the queen's internal angel-woman she must expunge.

While these varying interpretations of motherhood provide helpful perspectives on the tale, it is important to also consider the Grimms' collection within their social context. Zipes states: "The Grimms were able to institutionalize the literary fairy tale as a genre because they articulated the interest and needs of the German bourgeoisie and peasantry" (The Brothers Grimm 84). He goes on to cite the upward mobility of characters that identified with bourgeois virtues as fundamental to making these tales "quintessentially German" (Zipes, The Brothers Grimm 84). While Zipes likes to focus on the positive and upward social visions within Grimms' tales, he does not ignore the inherently patriarchal slant. He states, for example, that "it was due to their religious beliefs and upbringing that they stressed diligence, industry, honesty, order, and cleanliness as the ingredients necessary for success...their ethics assumed the form of selfvalidation that was also a validation of patriarchy in the family and male domination in the public realm" (Zipes, The Brothers Grimm 34). Clearly these ethics that Zipes calls "self- 
validation" struck a chord with a broader population of German people, specifically with the upper middle class and the bourgeoisie.

Snow White is the epitome of most of Zipes' listed qualities. She is honest, never once lying in the entire tale, industrious through her willing acceptance of the Dwarfs' request, "willst du alles ordentlich und reinlich halten" ("keep everything neat and tidy"), and well-ordered given her happy acceptance of that task (Grimm Schneewittchen 24) (Grimm "Snow White" 254). These ideals are bundled by the Grimms so that Snow White appeals to identifiable values of their mass audience. Given the disjointed state of Germany at the time coupled with constant threats and upheavals from the French, "Snow White" contributes to a collective comfort and national pride sought after in an unstable period through this collection of stories that clearly distinguish right from wrong. The Grimms tapped into the social consciousness of their time, making a collection of stories that, through their carefully crafted plots and senses of justice, spoke to a masses who shared their values.

\section{Surrogate Mothers in Disney's Snow White and the Seven Dwarfs}

Analogous to the Grimms' appealing to Germans in their time, Walt Disney reached out to 1930s middle class Americans with his animated shorts and features. Few have left such a remarkable impact on a culture's collective memory as Disney. Princesses waiting for true love and love cast as the most powerful antidote are tropes that came from Disney's now-long line of princesses, and of course his "Snow White" started it all. Snow White and the Seven Dwarfs was Disney's first feature length film, enchanting Depression-era audiences at its release in 1937. Snow White quickly became one of America's sweethearts, embodying a number of American ideals and values. Many of these ideals are similar to those in the Grimms' tale. Zipes notes: "In 
some way, [the Grimms] can even be considered [Disney's] ancestor, for he preserves and carries on many of their benevolent attitudes toward women" ("Breaking the Disney Spell" 37). Disney's Snow White is still beautiful, innocent, industrious, clean, and honest, but she also has qualities that distinguish her from the Grimms' character.

In therir article, "Walt Disney’s Snow White: Art, Adaption, and Ideology,” M. Thomas Inge breaks down the Disney version as it compares to the Grimm variant and the 1916 silent film Snow White, which Disney said he saw as a child. The 2009 rerelease of Snow White and the Seven Dwarfs contains an interview with Walt Disney, who states in the commentary that the 1916 silent film was "probably one of [his] first big feature pictures [he'd] ever seen." It makes sense that its plot stuck with him over the years, and helps to explain some of the departures his film made from the Grimms' tale that coincide with the 1916 film (such as the naming of the dwarfs and the emphasis on animal helpers.) Inge does note, however, that "it is not possible to know how many of these similarities are attributable to coincidence and how many to distant childhood memories on the part of Disney" (Inge 135). The fact that which "Snow White" text Walt Disney referenced has never been found also makes the possibilities for different readings through alternate translations endless. One key feature of both the Grimms' tale and the 1916 film that is no longer present in the Disney animation, however, is the natural mother. In interviews, Walt Disney has attributed this choice of omission to the need for a faster moving plot, as well as to avoid a beginning that was too sad (although they did not mind pulling that trick with Bambi 5 years later.) No matter what fueled the decision, however, it is an omission that drastically alters the interpretation of the conflict between Snow White and the evil Queen. Gilbert and Gubar's interpretation relies on the connection between the natural mother's transformation into the stepmother, as it is partially what fuels the stepmother's hatred of Snow 
White. More importantly, as Snow White is the same as her natural mother by the time she and the prince wed, she is doomed to transform into the monster woman as her mother did before her. This cyclical understanding of the role of women in society is lost in the Disney version without the natural mother's desires and death framing the narrative. Instead, the film invites the comparison between Snow White and her stepmother as maternal figures. Their connection is not lost on Gilbert and Gubar's reading of the Grimms' tale, however: “...the Queen and Snow White are in some sense one: while the Queen struggles to free herself from the passive Snow White in herself, Snow White must struggle to repress the assertive Queen in herself' (Gilbert and Gubar 41). This self-repressing is not as applicable, however, to the Disney film, as the missing natural mother removes the initial comparison between the stepmother and an "angel woman," which is an omission that brings the Disney version closer to Bettelheim's interpretation of stepmothers as bad mothers needing an example of a 'good mother' for comparison. Instead of understanding Snow White and the stepmother's conflict as something continuous, as Gilbert, Gubar, and Bettelheim all imply, the Disney film creates a distinctly binary relationship between the stepmother and Snow White that boils down to evil and good. This binary exists in the Grimms' tale, but it is between the 'good' daughter and 'evil' stepmother and the "good mother" and the "bad mother" rather than solely on Snow White and the queen, placing a larger emphasis on Snow White as the only symbol of pure goodness in the Disney version.

The binary in Snow White and the Seven Dwarfs is established immediately in the storybook-page prologue that states: "Once upon a time there lived a lovely little Princess named Snow White. Her vain and wicked Stepmother the Queen feared that some day Snow White's beauty would surpass her own" (Hand Snow White). Straightaway Snow White is described as 
little and lovely while the Queen is vain and wicked. Thanks to these descriptions, it is abundantly clear before the characters even occupy the screen that Snow White is the heroine and the Queen is the villain, and their character design only confirms these definitions. Snow White's purity shines through, despite her rags, in her youthful expressions, while the stepmother is in very dark, conservative clothing with an unsettlingly malicious face. Their voices also show their placements, as Snow's singsong voice is placed against the Queen's deeper, sinister one. Even their movements define their characters, as Snow White moves gracefully through her days while the Queen remains stiff and rigid. Every decision that went into the development of these characters clearly sought to divide them on as many levels as possible, making their division as clear as day and night. Their divisions as maternal figures, while not as obvious as their external qualities, are also portrayed as inverse. The Queen tries to kill Snow White, showing her position as the monster woman and bad mother, while Snow White willingly takes on the care of seven dwarfs, showing her position as the angel woman and good mother.

The positions of Snow White and the Queen can be interpreted as examples for female viewers: Snow White is the model for potential and actual mothers to follow, and the Queen is the representation of actions they should avoid. The Queen has substantially less screen time than Snow White (only appearing as bookends on the film and absent in the middle) but that time is spent highlighting her maliciousness as effectively as possible. After the prologue she is shown as a vain woman speaking to the magic mirror, as a scheming killer recruiting the huntsman, as a witch mixing her potions, and finally as a murderer tricking Snow White into eating the poisoned apple. All of these scenes are short and direct, but the longest, her potion brewing and transformation sequence, reveals more about her character than much of the content prior to it. Not only is the Queen malicious and vain, but she even frightens the crow (a type of 
familiar) that watches her. Paralleled with Snow White's constant interactions with animals, the crow's actions around the Queen show a combination of fear and disgust with someone who is impure and loathsome. The only animals that gladly follow the Queen are the vultures, clear symbols of death, who ultimately turn on her. They act as representations of the Queen's priorities, being only out for themselves.

Along with the crow's reaction, the brief scene in which the stepmother turned hag kicks a vessel water at the skeleton of a man who died reaching for it saying, "thirsty? Have a drink!" strongly portrays her uncompassionate character as someone who finds humor in her own cruelty. While it only lasts for a minute, this skeleton sequence is indicative of her character on a deeper level than almost anything prior to it. Each of these small moments constructs the Queen as someone who should not be mimicked by the viewer, her death sealing this portrayal by implying that cruelty, maliciousness, and murderousness only leads to death and defeat.

Contrasting her stepmother's position as the role model no one should follow, Snow White is given a lot of attention and opportunity to prove herself as the perfect woman. The scenes in which she is established as a good mother display her as stern, yet playful and caring. Each attribute is important and pushes her maturity past that of her predecessor in the Grimm variant, who does only what the dwarfs ask rather than take the initiative to offer to cook and clean in order to stay like Disney's Snow White. Grimms' Snow White is a positive female role model, but her attributes are used to show her as a good girl and not a good mother. Amy Davis explains in her book Good Girls and Wicked Witches: Women in Disney's Feature Animation that "the general perception of popular images of women during the [1930s-1950s] is that the 'happy homemaker' is an image of the 1950s alone, the fact is that she was very much alive and well throughout the Depression years" (Davis 118). Davis goes on to explain that "the emphasis 
on beauty throughout the 1930s, 1940s, and 1950s was upon the soft, physically comforting, inviting,...mature body of a young woman. An attractive young wife and mother (or at least a woman who would achieve these feminine goals soon) was the image most seen in fashion and house-keeping magazines... of this era" (Davis 118). Her physical characteristics as well as her actions place Snow White perfectly into that depiction of women. She cooks, cleans, takes care of the 'little ones,' and enjoys her life as a mother, doing it all with grace and a smile. In order to understand specifically how Snow White represents the perfect American woman, the different scenes in which she acts as mother are to be analyzed.

The beginning of Snow White's motherhood comes with her discovery of the Dwarfs' cottage. Their cottage is a key departure from the Grimms' tale, as "In dem Häuschen was alles klein, aber so zierlich und reinlich, dass es nicht zu sagen ist" ( "everything in the house was tiny and indescribably dainty and spotless") (Grimm Schneewittchen 18) (Grimm "Snow White" 251). In complete contrast, the house of the dwarfs in Disney's version is filthy, creating a situation for which Snow White can use her 1930s-approved action as a female to save the day: cleaning. Unlike the Grimms' Snow White, Disney's heroine assumes the house belongs to seven children, exclaiming "from the look of this table, seven untidy little children!" soon after entering the cottage (Hand Snow White). This begins Snow White's projected infantilism on the dwarfs. Through the dwarfs' acting as surrogate children, Snow White is able to enact the most important female roles of the time, namely to be a good housewife and caretaker. Even after she discovers that the dwarfs are not children, Snow White presents herself as a mother to them. During their introductions she talks to them like children, particularly when impersonating Grumpy while guessing his name. 
If Snow White's playing house wasn't clear enough to the viewer, her ordering the dwarfs to wash before dinner establishes her as a surrogate mother without doubt. It begins with her instruction to the child/children, moves into the resistance from them through their lying, then to Snow White catching them, and finally to her command and threat of punishment. As soon as Doc lies about washing, Snow White takes a skeptical tone and places her hands on her hips. This scene directly places her in a situation that mimics the position of the parent. As the mother she knows they are lying, but she plays along asking, to see their hands. The dwarfs act like caught children, hiding their hands and backing away from her. The proof of their uncleanliness brings about the order: "march right outside and wash or you'll not get a bite to eat" (Hand Snow White). The phrasing, paired with her stance, is exactly how a child would expect a parent to act. Snow White is playing the mother as best she can, and it is no surprise that her actions fit within the established norms of motherhood as established by films featuring maternal melodrama.

In her final scene of motherhood, Snow White wishes them goodbye on their way to work. Her kisses on the forehead are like those a mother comforting children on their way to school, and the dwarfs' immature reactions reaffirm their adolescent mindsets yet again. All three of these scenes work to establish her as the positive mother, affording American girls and women an example of how a good housewife should behave. However, as is the case with any idealization, Snow White is not to be confused with a representation of all American women. Instead the middle-class audience's acceptance and promotion of her as a popular character establishes her as an icon of what a woman hopes to embody. Why the middle class and not the poor or wealthy? As Davis points out, “....in the first half of Hollywood film history, American society as a whole tended to assume that its members were white and middle-class..." (Davis 
118). When considering this alongside Disney’s statement that “...80 percent of our audience are women"5 an idea of the target audience can be gathered as white, middle class women (Davis 110). Knowing his primary audience, Disney successfully tailored the film to be what women could aspire to through the character of Snow White.

Her connection to mother was not all Snow White accomplished as a protagonist, embodying a characteristic with which both male and female viewers could relate: positive work ethic. This concept is one of the primary self-images of Americans during Walt Disney's reign, with himself not excluded. Having worked his way up from humble origins, he “...felt drawn to fairy tales because they reflected his own struggles in life...and became a success due to his tenacity, cunning, courage, and his ability to gather around him talented artists and managers..." (Zipes, "Breaking the Disney Spell” 31). Walt Disney’s progression from a small time animator to entertainment mogul has become the stuff of American legends since his death, representing the end result of the American idealization of what hard work brings. Through the character of Snow White and her seven surrogate children, Disney presented this dream in an era where dreaming was sorely needed.

To start, Snow White sets about cleaning the house without being asked, recognizing that the way to live is through working hard and not asking for favors. Her spunk coupled with this attitude towards work would have been something to be admired during the harsh social climate of Depression-era America, when work was scarce and often carried out under dangerous or poor conditions. Unlike the Grimms' tale, in which the dwarfs show Snow White the value of work, Disney's heroine has already internalized the concept, furthering Disney's indication that work ethic is just part of being the idealized American. The film continues to push this emphasis on

\footnotetext{
${ }^{5}$ A quote found in Disney's storyboard notes for a sequence in Snow White and the Seven Dwarfs that was later rejected.
} 
work (despite the dwarfs acting like children more often than not) when it transitions straight from Snow White's song, "Whistle While You Work," into the Dwarfs' introductory song, "Hi Ho." The dwarfs may be children to Snow White, but they are still "men" (as they call themselves collectively), working all day and finding fulfillment in that work.

Zipes takes the importance of the Dwarfs as representatives of American society a step further when he argues, "the dwarfs are little workers...their names...suggest the composite humors of a single individual. They represent the healthy instincts of a person" (Breaking the Magic Spell 127). This view of the dwarfs deepens a viewer's connection to them, as anyone can relate to all of these simplified fragments of themselves. Bettelheim, however, finds the dwarfs to be a symbol of "pre-oedipal existence" in the Grimm version, and vehemently detests the naming of the dwarfs in the Disney film. He states in a footnote:

“Giving each dwarf a separate name and distinctive personality... seriously interferes with the unconscious understanding that they symbolize an immature pre-individual form of existence which Snow White must transcend. Such ill-considered additions to fairy tales, which seemingly increase the human interest, actually are apt to destroy it because they make it difficult to grasp a story’s deeper meaning correctly" (Bettelheim 210).

While Bettelheim may view the Grimms" dwarfs as more symbolic of an "immature...existence" than the dwarfs in Disney's film, arguably the named seven still embody those pre-oedipal traits. Despite their new personalities, everything the dwarfs do ends up making them look increasingly child-like (both in relation to Snow White's maternal acts and as "men" in general), making them more pre-oedipal than Bettelheim credits. Dopey, as the only dwarf unable to speak, almost embodies this pre-oedipal stage more when one considers that he is incapable of doing anything that is not overtly childish. A large cause of this behavior is to create slapstick comedy, but in 
spite of this Disney's dwarfs are just as symbolic of an ideal and uncomplicated lifestyle as the dwarfs in the Grimms' text (which is later highlighted in their lengthy dance sequence.)

The dwarfs' prominence in the film is a clear divergence from the Grimms' tale, making their purposes all the more relatable to the Americanization of the film. Ultimately the dwarfs act as children more than as men, and while they may work hard in the mines day in and out, they are portrayed as Snow White's surrogate children more than as her protectors throughout the bulk of the film. The dwarfs in the Grimms' tale repeatedly warn Snow White not to listen to the Queen who approaches disguised during her the three different appearances, but the child continuously ignores them and nearly perishes. Those dwarfs are wise and clean, while Disney's are goofy and unkempt. The reversal of roles between Snow White as the taker of advice and the giver of advice between the Grimm and Disney variants reaffirms Snow White's placement as a competent mother in the film, rather than the developing child seen in the literary tale. Without the natural mother even briefly entering the context of the Disney film, there is no "good mother" to be contrasted with the Queen. Therefore the decision to make Snow White a maternal figure ultimately provides the needed opposition between these good and bad mothers, allowing the film to reinforce positive American values and actions the in the same way "Snow White" reinforced those of $19^{\text {th }}$ century Germany.

\section{Once Upon a Time's Modern Mothers}

Mothers are given a whole new identity in Once Upon a Time as they fight for their child's safety and happiness. The tension that is lost between the natural mother and unnatural mother in the Disney version returns in the show, but with a surprising new twist. Snow White ${ }^{6}$ has an adult daughter named Emma Swan who is in conflict with the Evil Queen, Regina. Their

\footnotetext{
${ }^{6}$ Hereafter referred to as just "Snow" as she is more commonly known on the show.
} 
conflict is not over who is the fairest of them all, but over Emma's biological son, Henry, who has been adopted by Regina. The stepmother versus daughter conflict remains in Regina's and Snow's fairy tale world back story, but new maternal conflict arises out of the natural mother versus foster mother (the equivalent to a stepmother) conflict between Emma and Regina. These overlapping plots allow for a revised treatment of both Disney and Grimm women, as the stepmother against child (Regina and Snow) conflict, and the natural mother against unnatural mother (Regina and Emma) struggle are explored simultaneously.

The premise of the series involves the discord between three maternal figures: Regina Mills (the Evil Queen), Mary Margaret Blanchard (Snow White), and Emma Swan (Snow White's long lost daughter.) Regina casts a curse on everyone from the fairy-tale world and sends them to a new land (our world) as a way to punish Snow White and those who love her. Before Regina casts the curse, however, it is prophesied that the daughter of Snow White and Prince Charming (the nickname given to him by Snow White) will find them and save everyone who is cursed on her $29^{\text {th }}$ birthday. The couple manages to smuggle the baby to the new land before the curse takes effect, and they are cast out of their fairy tale home. This new land is Storybrooke, Maine (upon hearing this name for the first time Emma appropriately responds with “Storybrooke? Seriously?") (“Pilot” 2012). No one can leave and there have never been any visitors up to the arrival of Emma. Moreover, everyone who is cursed is suspended in time, and Regina and Mr. Gold (Rumpelstiltskin) are the only two who remember their fairy tale identities. ${ }^{7}$ While this is not the first example of bringing fairy tale characters into the modern age (the comic book series Fables, first published in 2002, and the Disney film Enchanted, released in 2007, are other examples of crossing the two,) it has proven to be very successful.

\footnotetext{
${ }^{7}$ Besides the Snow White family focus, the show follows a number of characters from well-known fairy tales, specifically from the Disney canon of variants, as they navigate both their 'true' lives as fairy tale characters in flashbacks, and 'average' lives as regular people in the present.
} 
Being that it is partially set in an "average" town, it is no surprise that the series is littered with a number of soap opera tropes and scandals, including comas, affairs, heartbreak, emotional distance, and petty spats for dominance. Even with all of those distractions, the primary plot always returns to Regina, Snow, and Emma. The ability to have a wandering plot is something unique to television serials, marking an inherent difference between the Disney film, the Grimms' tale, and this show. Moving in and out of conflicts fluidly while building characters through back stories is a privilege neither the Grimms nor Disney could afford. Fairy tales are generally considered to be short pieces, leaving little room for complex and often morally ambiguous characters. Instead, wonder tales like "Snow White" rely on situational elements, magic, and didactic conflicts to create their intriguing plots. Disney shortened the Grimm tale further for the feature length film, feeling that the expanded episodes in which the witch comes back three times did not work well for the film's dramatic pacing. ${ }^{8}$ In this respect there are benefits for the television series: fleshed out characters, deeper conflicts, and time to explore more perspectives. However, carefully constructed subplots create a number of distractions from the key conflict between the three mothers, which decreases the dramatic impact of their clashes over time as their confrontations become increasingly periodic and less thrilling.

Other concerns about the show rise not out of the genre, but the approach to the material. As mentioned before, Once Upon a Time primarily relies on the established Disney canon of fairy tales when creating their newly envisioned heroes and heroines. They use the widely known films as the basis by which changes are to be measured. Of course other non-Disney fairy tales are added (Rumpelstiltskin, Little Red Riding Hood, and Hansel and Gretel are a few,) but those

\footnotetext{
${ }^{8}$ While Disney did add scenes, such as the dance sequence and the washing sequence, they worked toward the entertainment value of the film rather than the plot. In this way Disney further developed the characters and kept audiences interested and enchanted with the animation, showing his strategic differences when using film as a medium in a consumer culture.
} 
that have a Disney version-use their well-known film predecessors to inform a character's unspoken history. This approach makes the show vulnerable to cliché references and motivations. Everything is solved by true love, in pure Disney fashion, and losing true love is enough to push a character to do evil. While this is not the only cliché element in the show, it is the most prominently displayed through dialogue, action, and solutions. Examples include Charming and Snow's “I will always find you” mantra, Regina’s motivation against Snow revolving around the death of her true love, and Emma's breaking the curse with the power of true love through kissing Henry. Even with these shortcomings, however, the show has managed to break free of its Disney roots through the new setting of Storybrooke.

Storybrooke does not have the fairy tale endings that one expects. Instead it is a place where happiness is postponed in soap-opera style. Lovers from the fairy-tale land are disconnected or on the rocks, children are not united with parents, and few strong friendships are displayed. If anything the town offers the antithesis of what someone who has interacted with Disney films expects out of a fairy tale. All of this unhappiness stems from female conflict, the curse being set by Regina who is seeking revenge against Snow White, reminding a viewer that vengeance never really wins. Instead, it is pure maternal love that has the final victory at the close of the first season, as Emma and Henry are reunited. The good mother is rewarded while the bad mother is punished. Unlike the Grimm and Disney versions, however, the Evil Queen does not die, but is punished through separation from her child. The change in Regina from Disney's Queen is apparent when one sees that she doesn't want to harm her child like her murderous predecessor, but rather will harm anyone who stops her from being a mother. This new angle on her character further emphasizes motherhood within this new variant of the Snow White tale, highlighting its importance to American viewers. This emphasis is drastically 
different from that of the Disney film that preceded it, as even the good mothers are no longer domestic angel women. Much in the way that the setting of Storybrooke offers a new space to invert characters, the show presents a stage on which to redefine what makes a mother good or bad.

There is a large amount of moral ambiguity in Once Upon a Time's characters and their motivations, as the writers purposefully create characters with complicated pasts that inform their decisions in the present. They become well rounded, relatable, and hard to define when compared to the characters in the prior variants. In comparison with the Disney and Grimm variants, Once Upon a Time destabilizes the binary understanding of good and evil. Has real change happened in these new reincarnations of Snow White and the Evil Queen? Does Emma Swan truly create a new conflict, or is she a new approach to an old theme? A closer examination of the characters of Snow, Regina, and Emma uncovers that values have undergone little change since the Disney variant, while the new twists offer a revealing image of the development made towards humanizing the enemy and promoting women with agency.

\section{Snow White and Mary Margaret: Balancing Old and New through a Double Identity}

In Once Upon a Time, Snow is the only one out of the three females discussed who has a true double identity. Regina has two personas, queen and mayor, but she is always "Regina," reconciling both her fairy tale and Storybrooke selves simultaneously. Snow, on the other hand, changes into Mary Margaret in Storybrooke and has no memory of her fairy tale identity. One would think Mary Margaret's new persona would depart from the Grimms' and Disney's Snow White characters, considering that, as a member of Storybrooke, she is a point of divergence from these tales. Surprisingly, however, Mary Margaret is more like Disney's Snow White than 
Snow, her made-over fairy tale double. Far removed from the expectations created by the Disney version, Snow proves to be warrior-woman instead of domestic icon. She is shown as a vagrant, hiding from Regina and surviving through theft. She is definitely not the Snow White from Disney, as she does not rely on the dwarfs, perform any domestic duties, or enact any maternal roles in the first season with the exception of the pilot episode. ${ }^{9}$ Mary Margaret, as her double, retains the old characteristics of Snow White and the show creates a new persona simultaneously through their pairing. Both halves do not make a whole, though; Mary Margaret does not have true love in her story while Snow does, but Snow does not retain Mary Margaret's innocence. Instead, Snow is the fighter and enabler of her own destiny, while Mary Margaret struggles to take control of her life.

Mary Margaret and Snow are easy to discuss as two characters, but the fact that they are the same person creates a conflict between their behaviors and attitudes. The pilot, however, works very hard to show them as the same in a way that is not replicated anywhere else in the first season. The overt-goodness of Mary Margaret is established through the introduction to her character, where she is seen as a grade school teacher in the classroom giving a speech about birdhouses. She carries a small blue bird as she speaks, the children attentively watching. She gently releases the bird out the window, and it flies to a blue birdhouse, perching while the children gasp in amazement. She finishes her speech with one of the main taglines for the show, "if you love them and they love you, they will always find you" ("Pilot"). While it is not in the immediate introduction to Snow in the pilot episode, the second scene features her leaning out

\footnotetext{
${ }^{9}$ In the pilot episode she is depicted being pregnant, giving birth, and being separated from her child. Without Emma's origin story beginning the series through Snow's maternal perspective, the tone regarding the series' central theme of motherhood and sacrifice would not be set properly.
} 
onto a balcony holding the same blue bird and releasing it from her hand into the sky. ${ }^{10}$ Moving beyond this immediate visual link, the show continues to relate the two through their inherently good characteristics. Mary Margaret is gentle and kind, and while she is not a mother she is put into the position of a grade school teacher, implying her position as a caregiver (just as Snow White was with the dwarfs in the Disney film.) Her concern for Henry furthers this position, showing her nurturing side as she gives him the book of fairy tales that spark his interest in the curse and subsequently finding Emma. Meanwhile, Snow is immediately cast in the position of the good mother.

Following the release of the bird on the balcony, Snow is shown as a devoted wife and mother. She talks about the lengths she is willing to go to in order to protect her baby and shows the deep love a mother has for their child even before birth. From this scene on, the fairy tale side of the pilot episode focuses on the protection of Emma and the establishment of Snow as the good mother. Snow's position as a mother is pushed to its limits in a way that does not connect to Mary Margaret's side of their character at all. Snow gives birth to Emma only to let her go in the hopes that the child will save them all. Her grief is portrayed through a shot panning from an exiting Charming to a mirror reflecting Snow wailing in agony. While Mary Margaret has no equivalent moment of sacrifice or pain, she and Snow are still portrayed as caregivers at the start of the first season. These representations quickly divide the demure Mary Margaret and the warrior Snow.

Mary Margaret's kind, caring, innocent character is upended later in the show in true soap opera style, during a story arch in which she becomes a home wrecker in order to be with the man she loves (who is Charming in the fairy tale land but unhappily married to another

\footnotetext{
${ }^{10}$ In the opening of the pilot episode (the technical introduction to Snow) Charming kisses Snow awake as one expects, but within the first 5 minutes it moves along to new material through the wedding scene where Regina announces her terrible curse.
} 
woman in Storybrooke.) This alteration of her character could be chalked up to soap opera drama (the whole plot involves a coma, after all); however, it simultaneously reflects the eventual boredom audiences have with unflawed, good characters, as well as their desire for Mary Margaret to fulfill Snow's fairy tale destiny by being with Charming. Without complicating their moral standing these too-good characters become broken-records of actions and dialogue, in this way the infidelity story arch places Mary Margaret in a position of moral ambiguity that presents her with the opportunity for character growth. The audience's knowledge that she is with her one true love based on the fairy tale background, coupled with her position as a home-wrecker in Storybrooke, creates doubt for viewers, which causes tension between the incompatible expectations of morality between the murky real world and the unambiguous fairy-tale land. Of course the whole dramatic series of events is forgiven and literally forgotten by the second season once the townsfolk realizes "it was for true love." Nonetheless, the early images of Mary Margaret in the first season are equivalent to the Snow White of Disney, a character who is so good-natured that animals trust her absolutely and who is nothing if not caring.

As Mary Margaret plunges into moral ambiguity, Snow's back story shows the woman behind the pilot episode's presentation of the mother. Though the show does create a substantially more active and sassy warrior-woman out of Snow through her time in exile, removing her further from the Snow White in Disney's film, this has become a commonplace tactic- almost a stereotypical characterization- in many other recent fairy tale adaptations. Hansel and Gretel: Witch Hunters (2013), Snow White and the Huntsman (2012), and Mirror Mirror (2012) are only a handful of examples in which a heroine who copes with being cast out by becoming a fierce fighter. Handing a heroine a weapon is an easy way to make her decidedly stronger than the fairy tale character she is based on, and to provide her automatically and 
superficially with more agency and power. True to the warrior-woman type, Snow continually engages in combat with a number of formidable opponents with her bow and arrows and defeats them. Generally these fighting characters are generically motivated by romance. In many cases the heroine is content with the lifestyle of an outsider until meeting her prince (as is the case with Once Upon a Time and Mirror Mirror), at which time the empowered goal of independence changes to the traditional goal of joining with her prince. True to this type, Snow Changes her goals from running from Regina and surviving skirmishes to risking life and limb to be with Charming.

These new warrior-women are active seekers of destiny rather than passive dreamers, but brandishing a sword does not change the end motive of marriage or at the very least a romantic relationship. Moreover, even when a character is cast as a warrior-woman she is commonly saved more than the male (Snow and Charming may always find each other, but when tallying successful rescues Charming takes the lead in the first season). In the case of Snow, marriage becomes a tool to create a mother out of the heroine, combining the mother seen in the pilot episode and the fighter seen through the rest of the season. This seemingly strong female fighter is used throughout the show to varying degrees of success.

While the interplay of Mary Margaret and Snow is a new twist on both the Disney and Grimm tales, the conflict between Snow and her stepmother remains a familiar plot device in Once Upon a Time. It is Regina's need for revenge that dooms everyone to Storybrooke in the first place, making everything that happens in the town a direct result of Snow and Regina's conflict, even if Mary Margaret does not remember it. The difference in this version's battle, however, lies in the motivation. No longer is the vain queen jealous of Snow's beauty. In fact, Snow's beauty is never alluded to as a motivator in the show with only one exception that is 
briefly stated in the first episode, when Snow says to Charming, "she poisoned an apple because she thought I was prettier than her" ("Pilot"). This discrepancy is never addressed later in the show, but rather serves as a testament to how much the pilot relies on the viewer's previous understanding of Disney's canon of "Snow White." Moving beyond the superficial motivation of vanity, Regina's loathing comes out of lost love.

It is discovered in Episode 18, "The Stable Boy," that Regina once had true love (with her stable boy) and lost it due to a very young Snow's inability to keep it a secret from Regina's scheming mother. The conflict between a mother and her child is pervasive in this back story, as it is Regina's mother, Cora, who kills the stable boy in order to make Regina marry the king (Snow's father.) Regina blames Snow for her secret fiancé's death and from that moment on begins plotting revenge. (Why she waits for Snow to grow up before exacting it is never truly explained in the show.) Her back story up to this episode (as it is rather far into the season) mainly consists of the different ways she attempts to ruin Snow's life and shows the choices she makes along the way that plunge her further into malice (such as killing her own father to enact the final curse). So while Regina may be the villain of this tale, evil is not something inherent, but is instead a product of negative choices. Episode 18 begins the long shift in how Regina is perceived; as her fall from innocence is abrupt and garners sympathy in a way that is absent for the prior stepmothers, marking the beginning of her occupation of a grey moral area.

This show maintains the conflict of stepmother versus daughter, despite Regina's creation of complications not present in the Disney and Grimm variants; but unlike the Grimm variants, it loses its Oedipal implications. Regina does not want to destroy Snow due to a fear of being usurped, but rather seeks pure revenge for lost love. Through the coupling of melodrama and the classic conflict between stepmother and child, Once Upon a Time invites its audience to question 
what motivates on to be evil in modern society compared to evil's intrinsic position in villains from the traditional tales. Unlike Snow White and the Seven Dwarfs, Once Upon a Time does not work to create ideal representations for its American society through near-perfect characters, but rather employs imperfect characters whose categorization as 'good' is earned rather than inherent.

\section{Emma and Regina: Imperfect Mothers}

In Once Upon a Time the dominant location for imperfect characters rests not within the fairy tale land, but in Storybrooke. Its location in the 'real world' creates a space that represents the ordinary, whereas wonder tales tend to express the extraordinary. This 'ordinary' space must be interesting to the audience somehow, and the easiest way to accomplish that is by populating it with characters who make mistakes and create discord (hearkening back to soap operas and neighborhood dramas.) This is where Mary Margaret's character is inverted, in the realm of melodramatic reality, and this is where the primary conflict between the natural and unnatural mothers is established. While characters' back stories are full of intrigue and diversion, the only overarching conflict that works to progress the plot is the fight for Henry between Regina and Emma.

Emma Swan, unlike Snow and Regina, has no direct predecessor in the Disney and Grimm variants. However, she does play into a previously established role from the Grimms' tale, as her ongoing conflict with Regina is that of natural mother against the unnatural one. Of course, Emma is not the mother in the window of the Grimms" "Snow White." Instead she is another warrior-woman like Snow. Unlike Snow, though, Emma fits within the category of emotionally guarded women who occupy many popular primetime shows (such as Dana Scully 
in The X-Files (1993), Kate Beckett in Castle (2009), and Audrey Parker in Haven (2010) to name a few). She gets by on her reasoning, does not back down, is emotionally scarred, and would rather be a guarded loner if given the chance. So while Emma may be unique to the tale of Snow White, she is not unique to prime-time television.

Her motherhood does set her apart from these other heroines, however, highlighting one of the ways in which this show uses motherhood to create new twists on old motifs beyond fairy tale convention. The introduction to Emma in the pilot episode portrays her as the expected tough woman, being the bombshell detective-type who is able to catch a bad guy while wearing very high heels (a point which is emphasized by shots that follow her feet.) She is the modern warrior woman: two steps ahead and gorgeous to boot. The arrival of Henry at her apartment and the surprise that Emma is his natural mother marks a shift in her future depictions, as motherhood does not coincide with sexy detective tactics and bombshell behavior. From this point on Emma undergoes a gradual change through which she transforms from a stranger into the dominant mother in Henry's life, despite his being raised by Regina. ${ }^{11}$

The relationship between Henry and Regina is depicted as strained; Henry believes she is the Evil Queen after all. However, Regina paints it differently during her first talk with Emma, saying: "am I strict? I suppose, but I do it for his own good. I want Henry to excel in life. I don't think that makes me evil, do you?" ("Pilot"). Her speech is sympathetic, as she is a single mom with a high-stress job trying to do what is best for her child. She occupies the demanding

\footnotetext{
${ }^{11}$ This transformation is drastic, as Emma can't even identify as a mother in the second episode, saying to Regina, "I know I'm not a mother - I think that's pretty self-evident - but I did have him, and I can't help it if he got in my head and I want to make sure he's okay" ("The Thing You Love Most"). Emma's journey from this second episode to the last may not be the highlight of every installment of the show, with some episodes being more heavy-handed than others. Through her work as the sheriff Emma is put into positions that force her to question her decision to give up Henry. In episodes like "The Price of Gold" and "True North," new situations in which Emma speaks about being a mother generate an understanding of why Emma let Henry go originally and now regrets it. As she continues along she grows more confident in her right to be in Henry's life, bringing about bigger fights with Regina, and ultimately placing her as the primary mother for Henry by the close of the first season.
} 
position of a single parent with an unruly child. At the outset there is no reason to believe she is an evil mother. While she is dangerous, she is never shown trying to harm Henry (even though she does inadvertently at the end of the season when he eats the apple turnover meant for Emma.) In fact Emma asks another character later in the first season, "do you think that she would ever hurt him?” to which he replies, "No. Never. I mean, everyone else, but not him” (“An Apple as Red as Blood"). Regina is never believed to be a bad mother by anyone but Henry and eventually Emma (whose bias is founded more on her own conflict and not on how Regina treats Henry as a mother). So why, if Regina is not actually a bad mother according to characters outside of her and Emma's battle, does Henry believe her to be evil?

The use of fairy tales by children to work through their own psychological problems is a literal image of Bettelheim's theories in action. Henry uses fairy tales as an opportunity to construct an argument for why his mother is evil, or the "bad mother" whom he rejects for her strictness, as Regina had mentioned to Emma. According to Bettelheim the "good mother" disappears to a child when the bad mother is present, hence the use of stepmothers as the archetype upon which the bad mother is projected in fairy tales. This remains true in "Snow White," as the natural mother disappears before the child has any conflict with her. While Regina isn't Henry's stepmother, she is his foster mother, comparable in its biological separation. Instead of waiting for the "good mother" to reappear in Regina as he works through these Oedipal stages, Henry seeks out his natural mother, a person onto whom he has projected all of his hopes. Why Henry knew it was his own natural mother who would be the savior of the town is never explained or even questioned, and it is a large plot hole. This is a large gap in the plot, considering that the whole premise of the show revolves entirely around Henry knowing, for a fact, that his own birth mother is the fabled abandoned child of Snow and Charming. However, 
in placing it in the context of Henry working through a "good mother"/“bad mother" pairing, the creation of his natural mother as the savior is logical, as she must be the antithesis to the Evil Queen in order to succeed in overthrowing his Oedipal bad mother. So while it may be a plothole, it is one that further proves that Emma and Regina are seen as either 'good' or 'evil' wholly based on Henry's skewed perceptions of them through an Oedipal lens.

This also explains how Emma is able to do no wrong according to Henry, who pushes for her to be the hero. Emma is by no means the perfect mother, yet Henry sees no faults in her. If one were to remove the fairy tale plot's image of Regina as evil from the Henry/Regina/Emma triangle, however, it becomes clear that Regina is actually the better mother. Yet, the audience follows Emma and is expected to side with her as the protagonist. Regina's cutthroat attacks against Emma help to solidify Emma as the 'good' character, as Regina is the first to be offensive in their conflict. It begins with their first clash near the end of the pilot episode, in which Regina threatens to "destroy" Emma if she dares to come near Henry again ("Pilot"). From this point on the two are locked in a constant struggle that ranges from snide remarks, to power grabs, to life-threatening actions. The two are on opposite ends of the spectrum morally, but throughout the first season their approach to conflict is the same: fight as hard as you can for what you want. This is one of the many instances in which their connections are stronger than they first appear. They are both strong women in positions of power, they both focus on beating their opponent above all else (even Henry's wellbeing, ) and they both refuse to back down. While their tactical approaches oppose one another, they both do everything in what they believe to be are Henry's best interests.

By the final episodes of the first season, Emma has become confident in herself as a mother, and feels she deserves to take back Henry. In the same conversation where Emma is told 
Regina would not hurt Henry, she asserts, "I'm his mother," to which the other character responds, "Yes, you are, and so is Regina" ("An Apple as Red as Blood"). This understanding of their pairing is crucial to interpreting their positions as mothers. Neither can be the only mother to Henry, therefore they must either find a compromise or destroy each other. Emma's and Regina's true dispositions are reinforced when they decide which of those two paths to follow. Emma seeks a compromise, agreeing to leave Storybrooke on the condition that she can see Henry again. Regina seeks destruction, procuring the same apple with which she cursed Snow, and baking it into a turnover to feed to Emma. Ultimately her choice is the one that harms Henry in one of the most extreme examples of "magic [coming] with a price," as he is the one who is affected by the sleeping curse.

By changing the terms of conflict between the natural and unnatural mother, Once Upon a Time is able to revaluate and expand upon the Disney tale, from which it predominately pulls inspiration, while revisiting themes from the Grimms' fairy tales through Emma's position as the natural mother. ${ }^{12}$ The new emphasis of the show rests upon defining family. During the pilot Emma is shown as alone and depressed, and she later admits that the wish she makes before Henry finds her is "that [she] didn't have to be alone on [her] birthday" ("Pilot"). Life is inherently better once she accepts motherhood, finding something to fight for and to bring her joy. The show gradually suggests that happiness cannot be found alone, and that the ultimate happiness comes from fighting to be with the ones you love (as shown in both Snow's and Charming's plots as well as Emma and Henry's.) The resolution of Henry's poisoning is the proof of this theme, as he is saved by the ultimate magic: true love's kiss. Emma delivers the

\footnotetext{
${ }^{12}$ Evidence for Once Upon a Time's basing itself on Disney more than Grimm is apparent in much of the show. Examples include: the dwarfs are named after the Disney characters, none of the other attempts to do away with Snow White (the comb and laces) are seen despite the episodic nature of the show providing the opportunity, and Snow is awakened by Disney's signature true-love's kiss.
} 
saving kiss, proving that motherhood is one of the purest loves powerful enough to break both Henry and Storybrooke's curses.

Despite Emma's rescue of Henry she still remains flawed as a mother, struggling to accept her role for much of the first season. Regina is equally imperfect, though, as she is incapable of compromise to the point that it drastically harms Henry. These imperfect mothers are more compelling, relatable, and tangible when compared to their predecessors. Considering their position as people rather than archetypes changes the conversations around how the viewing public responds to them as elements of popular culture. In the case of Disney's Snow White and the Seven Dwarfs, Snow White was a model for the American viewer. She was the hard working, positive, spunky symbol of what Americans found great about themselves and their future prospects despite the hard times of the Great Depression. The Grimms' Snow White was similarly an idealized representation, created as a representation for behavior and not a character with whom to foster an emotional connection. One cannot be as perfect as Snow White and Mary Margaret, but Emma's style of "good" is achievable. She does what is right, refuses to fight dirty, and keeps the moral high ground, making her actions easily copied. In a culture where everyone is told they can achieve great things, but most people do not, Emma is an outlet for realistic heroism. She functions in the same way that her prime time warrior women counterparts do, reaffirming the inclination towards characters that do good through their skills and strong morals.

Regina's position as a sympathetic villain also reflects a change in American popular culture since Disney's 1937 film. The binary between good and evil has become too simplistic, individuals instead are considered to be the outcome of their surroundings and their choices. Between Regina's pain from the actions of her mother and her subsequent descent into revenge, 
she is the perfect image of both poor surroundings and poor choices combined. She is given opportunities to make the right choice and be a good person, but she constantly denies them in pursuit of what she believes will bring her joy: vengeance. The Regina of "The Stable Boy" is long gone by the time she reaches Storybrooke, and the fall is what makes her intriguing. Similar to Emma's questioning her choice to give up Henry, Regina's path serves as a reminder about how choices affect one's happiness more than anything else.

\section{Conclusions}

The women's roles across these three "Snow White" variants speak to a major aspect of fairy tales: their ability to evolve over time. While this evolution may be subtle (such as Disney's Snow White becoming more maternal than the Grimms' character) or drastic (like Once Upon a Time's Snow becoming a warrior-woman), the importance rests in the characters ability to change, and never becoming stagnated. Without comparing and contrasting new and old variants, these shifts may be lost on viewers or readers who chose only to relate to the version that adheres to their personal societal context. Newer fairy tale productions like Disney's Snow White and the Seven Dwarfs and ABC's Once Upon a Time rely heavily on their connection with the tales that precede them; the Disney film alters the Grimms' German tale until it becomes Americanized, while Once Upon a Time revisits Disney characters and tropes in order to create new meanings and definitions for a changed American society. This television series requires the viewer to be familiar with Disney's canon of films, otherwise Once Upon a Time's transformation of Snow into a warrior-woman from her demure predecessor or the enactment of Regina's moral ambiguity and its subsequent impact would be lost on an unlearned viewer. 
In the case of the "Snow White" tale in particular, the characters of Snow White (or Mary Margaret in the case of Once Upon a Time) are consistently used to promote the best female role model possible for their societies. The Grimms' themes are carried over into Disney, but Disney's push for Snow White's role as a surrogate mother alters the reading of both her character and her conflict with the Queen. The changes in Once Upon a Time push Snow further into the 'good mother' role through her introduction in the pilot episode. Snow/Mary Margaret's imperfection separates her from her predecessors, however, pushing for a different interaction with audiences. The 'best female role model possible' is no longer idealized, but attainable through Once Upon a Time, because, unlike the Grimms and Disney, it seeks to promote flawed characters who are both more interesting and familiar for their faults in modern audiences' perceptions. Mary Margaret's entanglement with Storybrooke's Charmning creates drama for viewers, yes, but it also shows a heroine who is not inaccessibly perfect. In the times of the Grimms and Disney the need for perfect role models through their Snow White characters was a way to reassure audiences by reinforcing their embodiment of the values that made them strong as a society.

Modern culture is filled with idealizations of women and mothers in ads, movies, magazines, and television programs so that they have become daunting figures that can never be replicated rather than comforting ones, making relatable but flawed characters that still embody clear definitions of 'goodness,' like Emma and Snow, a welcomed alternative. Knowing that one of the heroines makes mistakes allows a viewer to see him or herself in that character more than in the Depression-era variant of Snow White. This shift from an idealized to an obtainable role model would not be recognizable without first knowing the place of Snow White in Disney and Grimm. This complex relationship between a tale, its time, its society, and other variants is what 
allows for a deeper understanding of how it functions in its individual society, and within its genre in general.

The depiction of the evil woman in particular can reveal much about the terms of maternal conflict within a tale, given that she is the driving force for change. For example, the treatment of Regina as the 'bad mother' completely separates her from the Disney and Grimm stepmothers, as she is no longer pure evil. Instead, she is portrayed as a complicated woman who made poor choices that led to being the 'bad mother.' The fact that someone's alignment as either evil or good relies on their choices and not an inherent character flaw (like vanity) is something else that modern audiences can relate to, as the world is not portrayed in simplistic terms of good and bad. Regina's new motivation sets the terms of her conflict with Emma, marking their battle as more complex than the struggle between Snow White and her stepmother in both the Grimm and Disney tales. While Regina is portrayed as the "bad mother," she is not out to kill Henry, who is at the center of the conflict, but rather is fiercely competing for him with the "good mother" Emma in a way that makes both of them just as imperfect as Snow. The first season's portrayal of the struggles in Storybrook is still cast in the light of good and evil, but in comparison to the tales before it is more so about the fight for motherhood. An understanding of shifts concerning motherhood in the American value system is clearly discernable considering Snow White and the Seven Dwarfs and Once Upon a Time alongside one another. The shift from perky housewife to fighting mother highlights the change from being a dutiful wife and mother to being a woman who fights for maternity in a life where it is not always convenient.

Ultimately fairy tales act as mirrors for the societies in which they are created, and these reflections are seen through characters, themes, and outcomes. While certain fairy tale authors, like the Grimm Brothers, worked to make moralistic tales in particular, the authors who seek to 
entertain often end up reflecting more of their society. When considering the role of the audience and the role of the author in regards to popular culture it would seem that it "... is neither an 'authentic' folk, working-class subculture, nor a culture simply imposed by the capitalist culture industries, but a 'compromise equilibrium'...between the two..." (Storey 4). It is for this reason that creators like the Grimms, Disney, and Horowitz and Kitsis clearly represent their respective social contexts. Their desire (and financial need in the case of Snow White and the Seven Dwarfs and Once Upon a Time) to appeal to the widest possible base of people generates material that (often inadvertently) reflects the way that an audience views its own values and ideals. The malleability of fairy tales, coupled with their simplistic plots and two-dimensional characters, offers creators the chance to reapply the tales to their own situations so that, if successful, they become pieces of popular culture. Fairy tales are mirrors that distill a society's needs, fears, hopes, values, and visions into a seemingly simplistic reflection that often portrays clearer images of how members of that society view themselves, creating a bond between that tale and the people transforming it into popular culture. 


\section{Bibliography}

"An Apple as Red as Blood." Once Upon a Time: The Complete First Season. Writ. Edward Kitsis, Adam Horowitz. ABC Studios, 2012. DVD.

Ashby, LeRoy. With Amusement for All: A History of American Popular Culture Since 1830. Lexington: The University Press of Kentucky, 2006. Print.

Bettelheim, Bruno. The Uses of Enchantment. New York: Vintage Books, 1989. Print.

Davis, Amy M. Good Girls and Wicked Witches: Women in Disney's Feature Animation. New Barnet: John Libbey Publishing, 2006. Print.

Dawley, J. Searle, dir. Snow White and the Seven Dwarfs. Perf. Marguerite Clark. 1916. Paramount Pictures Corporation. Film.

Gilbert, Sandra M, and Susan Gubar. The Madwoman in the Attic. New Haven: Yale University Press, 1979. Print.

Grimm, Jacob and Wilhelm. Schneewittchen. Berlin: Verlagshaus Jacoby \& Stuart, 2011. Print.

Grimm, Jacob and Wilhelm. "Snow White." The Annotated Brothers Grimm. Ed. Maria Tatar. New York: W.W. Norton and Company, Inc., 2012: 246-261. Print.

Inge, M. Thomas. "Walt Disney's Snow White and the Seven Dwarfs: Art, Adaptation, and Ideology." Journal of Popular Film and Television 32.3, (2004): 132-142. Electronic.

Hand, David, dir. Snow White and the Seven Dwarfs. 1937. Walt Disney Studios Home Entertainment, 2009. DVD.

Hibberd, James. "Once Upon a Time Casts Spell on Sunday Night." Entertainment Weekly 4 Nov. 2011: 23. Ebscohost Academic Search Premier. Web. 3 Feb. 2014.

Kawan, Christine Shojaei. “A Brief Literary History of Snow White.” Fabula 49.3, (2008): 325 342. Electronic.

"Pilot." Once Upon a Time: The Complete First Season. Writ. Edward Kitsis, Adam Horowitz. ABC Studios, 2012. DVD.

“The Price of Gold." Once Upon a Time: The Complete First Season. Writ. Edward Kitsis, Adam Horowitz. ABC Studios, 2012. DVD.

Smith, Wendy. "Happily Ever After.” American Scholar. 82.1 (2013): 105-108. Ebsco Academic Search Premier. Web. 10 October 2013.

“The Stable Boy." Once Upon a Time: The Complete First Season. Writ. Edward Kitsis, Adam 
Horowitz. ABC Studios, 2012. DVD.

Storey, John. Cultural Studies and the Study of Popular Culture. $2^{\text {nd }}$ ed. Athens: University of Georgia Press, 2003. Print.

“The Thing You Love Most.” Once Upon a Time: The Complete First Season. Writ. ABC Studios, 2012. DVD.

“True North." Once Upon a Time: The Complete First Season. Writ. Edward Kitsis, Adam Horowitz. ABC Studios, 2012. DVD.

Zipes, Jack. Breaking the Magic Spell: Radical Theories of Folk and Fairy Tales. Lexington: University Press of Kentucky Scholarly publisher for the Commonwealth, 2002. Electronic Kindle Edition.

---. "Breaking the Disney Spell." From Mouse to Mermaid: The Politics of Film, Gender, and Culture. Ed. Elizabeth Bell, Lynda Haas, and Laura Sells. Bloomington: Indiana University Press, 1995. 21-42. Print.

---. The Brothers Grimm: From Enchanted Forests to the Modern World. New York: Routledge, 1988. Print. 